\title{
UTILIZATION OF CRUDE TESTIS EXTRACT TO ENHANCE BROILER PRODUCTION IN THE HUMID TROPICS
}

\author{
G. N. EGBUNIKE, J. T. WILLIAMS and E. A. AGIANG
}

(Received 18 July, 2007; Revision Accepted 15August, 2007)

\section{ABSTRACT}

Two experiments were conducted to investigate the possibility of using aqueous testis extracts as growth promoters. In the first experiments, 100 Abore Acre chicks were assigned to four treatments in which the birds were given 0, 10,15 and $20 \%$ of a 3.3 $\%$ aqueous bull testis extract in drinking water ad libitum from week four to week eight while in the second experiment, 100 Anak broiler chicks were placed in five treatments with $0,10,15,20$ and $30 \%$ of the testis extracts, respectively from week two to week eight. Throughout the studies feed and water were supplied ad libitum. Live weight of the birds and weight gain were significantly $(p<0.05)$ increased by treatment in both experiments especially at 15 to $20 \%$ testis extract groups. Feed intake and water consumption increased with increase in the levels of testis extract in water, while feed conversion ratio showed inverse relationship and cost of feed remained stable. Cost of feed $/ \mathrm{kg}$ of bird dropped significantly $(p<0.05)$ while profit per bird and profit over cost of production were significantly elevated from 15 to $20 \%$ testis extract groups. Carcass characteristics in both experiments remained stable. Thus a broiler farmer can make good profits by using 15 to $30 \%$ inclusion of a $3.3 \%$ aqueous bull testis extract in drinking water.

\section{KEY WORDS: Testis extract, Broiler Production.}

\section{INTRODUCTION}

It has been observed that in developing countries the demand for meat is expected to grow by $2.8 \%$ per year, rising from 89 million tonnes/ year in 1993 to 188 million tonnes per year by 2020 (IFPRI, 1999). But in Nigeria animal protein intake by the average Nigerian is among the lowest in the world (Egbunike, 1997, Larmode, 1998). This is mainly due to poverty, high cost of animal feeds and hence high cost of animal products, political and economic instability and poor infrastructural development for livestock production.

In order to improve this situation within a short period, poultry production appears to be the most reliable among animals (Dipeolu, et al., 1996; IFPRI, 1999) since they are highly prolific, possess a high feed conversion ratio and are accepted by all, irrespective of religion. Broilers are chickens bred for meat production but the costs of raising them to table size is about 60 to $80 \%$ of the total expenditure on broiler production (Ogunfowora, 1984; Larry, 1993). This thus becomes an impingement on the profit accruable in the broiler enterprise. To ameliorate such a situation, there has been a stimulated and continued search for more suitable combinations of known nutrients and feed/ water additives that will increase the efficiency of production and rate of growth of the birds bearing in mind that the humid tropical climate is stressful and has adverse effects on livestock production (Adejumo and Egbunike, 1988). In this regard, additives like hormones, antibiotics and arsenicals like 3- nitro -4hydroxyphenyl arsenic acid have been applied in broiler production as growth promoters. The role of the antibiotics and probiotics in the modification of gut function and consequent growth enhancement has been adequately reviewed by Williams (1991). However, with the current economic climate of Nigeria, these additives are now out of reach of most broiler producers.

It is in the light of the above that there was need to look inwards for locally available and cheap materials that can be used as growth promoters in broilers. As feed intake, even in chicken, is compromised under tropical conditions (Ebgunike, 1986), drinking water, "the forgotten nutrient", was used as vehicle for the growth promoters. Crude bull testis extracts in drinking water were used as growth promoters in this study.

\section{MATERIALS AND METHODS}

Two experiments were carried out to investigate the effects of different levels of testis extracts in drinking water on broiler production.

\section{Experiment 1}

100 day -old Abore Acre broiler chicks were obtained for this experiment. They were given all required medications and vaccinations, fed a commercial starter diet containing $24.33 \%$ crude protein and $3,077 \mathrm{kcal} / \mathrm{kg} \mathrm{ME}$ for three weeks and thereafter randomly and equally assigned to four treatments with regards to testis extract inclusion in drinking water. Treatment $A$ served as the control with no testis extract while treatments $B, C$ and $D$ had the extracts included in drinking water at 10, 15 and $20 \%$ inclusion levels, respectively. The extracts were obtained weekly from the extraction and centrifugation at $4,500 \mathrm{~g}$ of an aqueous homogenate of bull testes without the tunica albuginea at $30 \mathrm{ml}$ of water/g testis. They were stored in the refrigerator $\left(+4 .{ }^{\circ} \mathrm{C}\right)$ until required every day. Thus all birds in treatments 10, 15 and 20\% were given these respective treatments from weeks 4 to 7 . Broiler starter and finisher feeds (Table 1) were given at weeks 1-4 and 5-8 respectively. Diets were analysed for their chemical constituents according to methods outlined by AOAC (1990). Feed and water were supplied ad libitum throughout the period of the experiment.

Feed intake was measured as the difference between the weight of feed served and that of feed left over at the end of the day while body weight gain was measured weekly as the difference between the body weight for the week and that for the previous week. Feed conversion ratio was the amount of feed intake per unit of weight gain.

At the end of the experiment all birds were sacrificed and blood samples collected into ethylene diaminetetra-acetic acid - treated bottles for haematological studies as reported by Coles (1974). The carcasses were thereafter defeathered, weighed and cut into parts, viz drumstick, thigh, back, breast, wing and neck. These parts and the liver and gizzards were then weighed.

G. N. Egbunike, Animal Physiology Laboratory, Department of Animal Science, University of Ibadan, Ibadan, Nigeria

J. T. Williams, Animal Physiology Laboratory, Department of Animal Science, University of Ibadan, Ibadan, Nigeria

E. A. Agiang, Department of Animal Science, University of Calabar, Calabar, Nigeria 


\section{Experiments 2}

100 day -old Anak 2000 broiler chicks were obtained and assigned equally to five treatments viz $0,10,15,20$, and $30 \%$ testis extract (as in experiment 1 ) respectively in drinking water from week 2 to week 8 when they were slaughtered.
Management of birds and data collection were as in experiment 1.

The data collected were subjected to analyses of variance as outlined by Steel and Torrie (1980) while the means were compared using Duncan's multiple range test (Duncan, 1955).

Table 1: Gross composition of experimental broiler rations (\%)

\begin{tabular}{|l|l|l|}
\hline Ingredients & Starter & Finisher \\
\hline Maize & 52.38 & 58.81 \\
Soybean Meal & 22.20 & 19.80 \\
Groundnut cake & 18.17 & 13.86 \\
Fish meal & 2.52 & 0.99 \\
Palm oil & 2.02 & 1.98 \\
Bone meal & 1.01 & 1.98 \\
Oyster shell & 1.01 & 0.99 \\
Vitamin premix & 0.25 & 0.25 \\
Salt & 0.25 & 0.25 \\
Methionine & 0.19 & 0.19 \\
Determined chemical composition & & \\
Crude protein (\%) & 24.33 & 21.36 \\
Crude fibre (\%) & 3.39 & 3.20 \\
Ether extract (\%) & 4.04 & 3.96 \\
Calcium (\%) & 1.33 & 1.22 \\
Phosphorus (\%) & 0.59 & 0.53 \\
Metabolizable energy (Kcal/ kg) & 3077.00 & 3132.00 \\
Calculated chemical composition & & \\
Methionine (\%) & 0.45 & 0.45 \\
Lysine (\%) & 1.15 & 1.00 \\
& & \\
\hline
\end{tabular}

\section{RESULTS}

The gross composition as well as the chemical composition of the diets are shown in Table 1. Crude protein levels in the starter and finisher diets were 24.33 and $21.36 \%$ respectively while the metabolizable energy was 3077-3132 $\mathrm{kcal} / \mathrm{kg}$.

The performance of broilers to testis extracts in drinking water in the first experiments is shown in Table 2.
Final liveweight of the birds was significantly $(p<0.05)$ higher in those on 15 and $20 \%$ testis extract treatment while weight gain followed the same trend except that it was more significantly enhanced at $20 \%$ testis extract group. Feed intake tended to increase with increase in the levels of testis extracts in the water. Also, feed conversion ratio improved with increase in the levels of testis extracts. Daily water intake increased from 200. $71 \mathrm{ml}$ in control group to $230.71 \mathrm{ml}$ in the $20 \%$ group although this difference was not significant.

Table 2: Performance of broilers on four different levels of testis extracts (Experiment1)

\begin{tabular}{|l|l|l|l|l|}
\hline \multirow{2}{*}{ Parameters } & \multicolumn{4}{|c|}{ Treatments (\% testis extracts) } \\
\cline { 2 - 5 } & 0 & 10 & 15 & 20 \\
\hline Initial liveweight (g) & 435.00 & 428.17 & 432.06 & 451.15 \\
Final liveweight (g) & $2160.11^{\mathrm{b}}$ & $2371.19^{\mathrm{b}}$ & $2553.01^{\mathrm{a}}$ & $2686.24^{\mathrm{a}}$ \\
Weight gain (g)/ bird/ day & $30.80^{\mathrm{c}}$ & $34.69^{\mathrm{bc}}$ & $30.80^{\mathrm{ab}}$ & $39.91^{\mathrm{a}}$ \\
Feed intake (g/day) & 106.96 & 102.80 & 106.16 & 108.67 \\
Feed conversion ratio & 2.17 & 1.85 & 1.75 & 1.70 \\
Daily water intake (wks 4-7: mls) & 200.71 & 214.43 & 220.36 & 230.71 \\
Cost of feed intake (N) & 138.33 & 132.93 & 137.36 & 140.76 \\
Cost of feed /kg bird (A) & $107.63^{\mathrm{a}}$ & $92.42^{\mathrm{ab}}$ & $86.99^{\mathrm{b}}$ & $84.19^{\mathrm{b}}$ \\
Profit (A bird) & $21.47^{\mathrm{c}}$ & $60.64^{\mathrm{b}}$ & $77.80^{\mathrm{ab}}$ & $92.78^{\mathrm{a}}$ \\
Profit (\% cost of production) & $6.21^{\mathrm{c}}$ & $17.71^{\mathrm{b}}$ & $21.84^{\mathrm{ab}}$ & $25.50^{\mathrm{a}}$ \\
& \multicolumn{5}{|c}{} & \\
\hline
\end{tabular}

\section{* $\quad$ At the end of the third week post hatching}

$+\quad$ At the end of the eight week post hatching

abc: Values in a row with different superscripts are significantly different $(P<0.05)$

Cost of feed per $\mathrm{kg}$ of bird was significantly reduced $(P<0.05)$ by treatment. Profit per bird and profit as percentage cost of production were significantly enhanced $(P<0.05)$. Profit per bird was 21.47 naira for control birds as against 60.64 , 77.80 and 92.78 naira for 10,15 and $20 \%$ testis extract groups, respectively. Regardless of the level of testis extracts in drinking water for the birds, both carcass characteristics (Table 3) and haematological indices (Table 4) remained unchanged.
In the second experiments in which we monitored the effects of higher testis extract inclusion levels, the response of the birds to the treatments did not follow any particular trend. Final liveweight and weight gain were highest $(P<0.05)$ at 20 and $30 \%$ testis extract treatments. Feed intake and cost of feed tended to increase with increasing levels of testis extract inclusion in drinking water. It is worthy to note also that cost of feed per $\mathrm{kg}$ of bird decreased with increasing levels of testis extract inclusion while profit per bird and as a percentage of cost production significantly $(P<0.05)$ increased (Table 5$)$. 
Table 3: Carcass characteristics of broilers on different levels of testis extracts (Experiment 1)

\begin{tabular}{|l|l|l|l|l|}
\hline \multirow{2}{*}{ Parameters } & \multicolumn{4}{|c|}{ Treatments (\% testis extracts) } \\
\cline { 2 - 5 } & 0 & 10 & 15 & 20 \\
\hline Dressing percent (\%) & 74.42 & 73.33 & 73.70 & 73.03 \\
Drumstick (\%) & 14.16 & 14.11 & 14.21 & 13.88 \\
Thigh (\%) & 18.18 & 17.66 & 17.03 & 17.54 \\
Back (\%) & 21.72 & 21.63 & 22.64 & 22.45 \\
Breast (\%) & 21.55 & 21.30 & 21.91 & 21.72 \\
Neck (\%) & 9.41 & 9.72 & 8.89 & 9.17 \\
Liver (\%) & 1.87 & 2.17 & 2.23 & 2.38 \\
Wing (\%) & 12.45 & 12.37 & 12.15 & 11.94 \\
Gizzard (\%) & 3.75 & 3.88 & 3.75 & 3.62 \\
\hline
\end{tabular}

Dressing percentage of the birds as well as the those of the drumstick, thigh, back, breast, neck and the gizzards tended to increase with the increase of testis extract in drinking water (Table 6).

Table 4: Haematological parameters of broilers on four different levels of testis extracts (Experiment 1)

\begin{tabular}{|l|l|l|l|l|}
\hline \multirow{2}{*}{ Parameters } & \multicolumn{4}{|c|}{ Treatments (\% testis extracts) } \\
\cline { 2 - 5 } & 0 & 10 & 15 & 20 \\
\hline PVC (\%) & 31.60 & 34.00 & 32.60 & 34.00 \\
Hb (g/dl) & 9.30 & 10.68 & 10.32 & 9.60 \\
RBC (x 10 $\left./ \mathrm{mm}^{3}\right)$ & 3.41 & 3.40 & 3.19 & 3.18 \\
WBC $\left(10^{3} / \mathrm{mm}^{3}\right)$ & 15.01 & 17.46 & 16.60 & 16.21 \\
Lymphocytes (\%) & 35.20 & 31.40 & 29.40 & 32.80 \\
Neutrophils (\%) & 61.40 & 66.80 & 68.00 & 62.20 \\
Monocytes (\%) & 1.40 & 1.60 & 2.00 & 1.80 \\
Eosinophils & 2.00 & 1.20 & 1.80 & 1.80 \\
\hline
\end{tabular}

\section{DISCUSSION}

The study reported here has shown that testis extract supplied via drinking water can enhance broiler production under the prevalent conditions of Ibadan. This is consistent with the fact that testis extracts contain testosterone produced by the Leydig cells in the interstitial tissue of the testis (Setchell, 1978; Kirby and Froman, 2000). Testosterone is the primary androgen in the adult male animals hence intact males utilize their feed efficiently, resulting in more rapid growth and the production of a leaner carcass (Booth, 1982). Quantitatively, growth is the increase in living substance/ protoplasm that may include cell multiplication (hyperplasia), cell enlargement (hypertrophy) and incorporation of materials taken from the environment. This growth and development of lean and fat have been highly associated with economic benefits.

Table 5. Performance of broilers on different level of testis extracts (Experiment 2)

\begin{tabular}{|l|l|l|l|l|l|}
\hline \multirow{2}{*}{ Parameters } & \multicolumn{5}{|c|}{ Treatments (\% testis extracts) } \\
\cline { 2 - 6 } & 0 & 10 & 15 & 20 & 30 \\
\hline Initial liveweight (g) & 40 & 40 & 40 & 40 & 40 \\
Final liveweight (g) & $1140^{\mathrm{b}}$ & $1230^{\mathrm{b}}$ & $1320^{\mathrm{ab}}$ & $1620^{\mathrm{a}}$ & $1390^{\mathrm{a}}$ \\
Weight gain (g)/ bird/ day & $19.64^{\mathrm{b}}$ & $21.25^{\mathrm{b}}$ & $22.88^{\mathrm{ab}}$ & $28.21^{\mathrm{a}}$ & $24.11^{\mathrm{a}}$ \\
Feed intake (g/day) & 69.05 & 69.85 & 76.15 & 72.50 & $73.78^{\mathrm{a}}$ \\
Feed conversion ratio & 0.86 & 0.82 & 0.82 & 0.81 & 0.70 \\
Cost of feed intake (N) & 130.00 & 131.51 & 143.38 & 136.50 & 138.91 \\
Cost of feed /kg bird (A) & $114.04^{\mathrm{a}}$ & $106.92^{\mathrm{a}}$ & $108.62^{\mathrm{a}}$ & $84.26^{\mathrm{b}}$ & $99.94^{\mathrm{ab}}$ \\
Profit (N bird) & $17.00^{\mathrm{c}}$ & $22.50^{\mathrm{bc}}$ & $40.50^{\mathrm{a}}$ & $30.83^{\mathrm{ab}}$ & $41.40^{\mathrm{a}}$ \\
Profit (\% cost of production) & $6.40^{\mathrm{c}}$ & $9.00^{\mathrm{bc}}$ & $14.69^{\mathrm{bc}}$ & $15.00^{\mathrm{ab}}$ & $18.68^{\mathrm{a}}$ \\
\hline
\end{tabular}
abc: $\quad$ Figures in a row differently superscripted differ significantly $(\mathrm{P}<0.05)$

Table 6: Carcass characteristics of broilers on different levels of testis extracts (Experiment 2)

\begin{tabular}{|l|l|l|l|l|l|}
\hline \multirow{2}{*}{ Parameters } & \multicolumn{5}{|c|}{ Treatments (\% testis extracts) } \\
\cline { 2 - 6 } & 0 & 10 & 15 & 20 & 30 \\
\hline Dressing percent (\%) & 75.40 & 70.96 & 82.00 & 80.23 & 81.98 \\
Drumsticks (\%) & 12.70 & 11.49 & 16.00 & 14.62 & 14.91 \\
Thigh (\%) & 15.85 & 11.49 & 15.00 & 13.85 & 20.18 \\
Back (\%) & 21.95 & 17.24 & 26.00 & 23.08 & 27.19 \\
Breast (\%) & 24.39 & 17.24 & 26.00 & 23.08 & 28.95 \\
Neck (\%) & 4.87 & 4.60 & 9.60 & 6.92 & 7.87 \\
Liver (\%) & 2.44 & 4.60 & 1.20 & 3.85 & 2.63 \\
Wing (\%) & 9.76 & 8.05 & 13.00 & 6.92 & 11.40 \\
Gizzard (\%) & 3.66 & 2.30 & 4.00 & 4.61 & 7.89 \\
\hline
\end{tabular}

The chemical compositions of the starter and finisher diets, especially the crude protein and metabolisable energy, are within the ranges recommended for broilers by Olomu (1977),
Njike and Ndife (1980), the National Research Council (1996) and Oluyemi and Roberts (2000). Thus the diets are ideal for promoting normal growth in the chickens. 
The final liveweight and weight gains were enhanced in broilers on water treated with testis extracts especially at 15 and $20 \%$ levels while feed intake and feed conversion ratio remained relatively stable will be construed to indicate the anabolic effects of androgens/testosterone in the extracts as already indicated by Booth (1982). This implies that the metabolic efficiency and dietary utilization by the birds were improved by the treatment (Huang et al., 1993). It also suggests that the inclusion of testis extracts (testosterone) in the water reduced the adverse effects of the hot climate on the performance of the birds probably by increasing the availability of nutrients and energy to the animals for growth. It is also possible that the increase in liveweight and growth rate was influenced by increases in the number of muscle fibres in the animals as suggested by Dwyer el. al., (1993).

The carcass yield as well as the relative weights of the various parts, especially the breast, agreed with the report of Berri (2000) and Nworgu et al (2001) but not with that of Pollock (1997). It is worthy to note that although the results of carcass characteristics and haematological indices appeared similar, the profit per bird and profit over cost of production were significantly elevated especially at the inclusion rates of testis extract of 15 and 20\% (Experiment 1) and 15, 20 and $30 \%$ (Experiment 2). Thus for a farmer producing about 2, 000 broilers per month using $15-30 \%$ inclusion of a $3.3 \%$ bull testis extract the expected profit of his enterprise will be at least $\mathrm{N}$ $11,324.00 /$ month or $N 1.36$ million/year which will be about $20 \%$ of production cost.

In conclusion, this study has shown that in the absence of the otherwise expensive commercial growth promoters, broiler producers can utilize bull testis extracts at $15-30 \%$ of a $3.3 \%$ testis extract and still make good profits in a humid tropical environment.

\section{REFERENCES}

Adejumo, D. O. and Egbunike, G. N., 1988. Effect of thermal stress and water deprivation on acetylcholinesterase activity in the pig brain and hypophyses. Int. J. Biometer 312: 108-111.

A. O. A.C., 1990. Association of Official Analytical Chemists. Official Methods of Analysis $15^{\text {th }}$ Ed., Washington D.C.

Berri, C., 2000. Variability of sensory and processing qualities of poultry meat. World Poult. Sci. J. 56 (3): 209-224.

Booth, W. D., 1982. Testicular steroids and boar taint. In: Control of Pig Reproduction (D. J. A. Cole and G. R. Foxcroft, eds), Butterworth Scientific, London.

Coles, E. H., 1974. Veterinary Clinical Pathology. $2^{\text {nd }}$ Ed., W. B. Saunders Co., Philadelphia.

Dipeolu, M. A., Eruvbetine, D. and Williams, T. J., 1996. Indigenous chicken rearing under village conditions. Int.J. Anim. Sci. 11: 63-67.

Duncan, D. B., 1955. Multiple range and multiple F-tests. Biometric 11: 1-42.

Dwyer, C. M., Fletcher, J. M. and Stickland, N. C., 1993. Muscles cellularity and postnatal growth in the pig. J. Anim Sci. 71: 3339-3343.

Egbunike, G. N., 1986. Adaptation of improved poultry breeds to the tropical climatic condition of Nigeria. Invited paper at the Advanced Poultry Short Course organized by B. B. Vet. Medical Services, Mitchell Farms and U. S. Feed Grains Council, Lagos, December 8-11, 1986

Egbunike, G. N., 1997. What is Animal Science and how can Nigeria get out of malnourishment? Proc $2^{\text {nd }}$ Ann. Confr. Anim. Sci. Assoc. of Nigeria, 16-17 Sept., 1997, Ikeja, Lagos, pp 1-12.

Huang, C. Y., Koh, T. J., Chen, H. J., Jiang, S. Y. and Wang,

P. L. 1993. Effect of testosterone injection on maintaining semen quality in boars during the hot season. Research Report, Animal Industry Research Institute, Taiwan Sugar Corporation N0. 1993, 47-53.

IFPRI., 1999. Livestock to 2020. The next food revolution. Food, Agriculture and the Environment, Discussion Paper No. 28, Washington DC, USA

Kirby, J. D. and Froman, D. P., 2000. Reproduction in male birds. In: Sturkie's Avian Physiology, $5^{\text {th }}$ ed. (G. Causey Whittow, ed . ) C. A. Academic, San Diego pp 597-615.

Larmode, A. G., 1998. Scenario building for the Nigerian livestock industry in the $21^{\text {st }}$ century. A paper presented at the silver anniversary Confr. NSAP, Gateway Hotel, Abeokuta.

Larry, E. N., 1993. Broiler Feeding and Management. Poultry International 32(1): 70-72.

Njike, M. C. and Ndife, L. I., 1980. Protein and energy requirements of Poultry, $9^{\text {th }}$ ed., National Academic Press, Washington DC.

Nworgu, F. C., Egbunike, G. N., Ogundola, F. I., Salako, R. A. and Fakeye, O. E., 2001. Effects of different protein levels on the performance and carcass characteristics of broilers. ASSET Series A 11 (2): 75-87.

Ogunfowora, O., 1984. The structure of cost and returns in feedmill operations. In: Feedmill Management in Nigeria, Federal Livestock Department, Ibadan University Press: 107-108.

Olomu, N. J., 1977. Optimum protein and energy levels for finishing broiler chickens in a tropical environment. Niger. J. Anim. Prod. 4: 239-253.

Oluyemi, J. A. and Roberts, F. A., 2000. Poultry Production in Warm Wet Climates Spectrum Books Ltd., Ibadan.

Pollock, D. L., 1997. Maximizing yield. Poultry Sci._ 7611311133.

Setchell, B. P., 1978. The Mammalian Testis, Paul Elek Books Ltd., London.

Steel, R. G.D and Torrie, J. H., 1980. Principles and Procedures of Statistics. A Biometrical Approach, $2^{\text {nd }}$ ed., McGraw-Hill Book Co. Inc., New York.

Williams, P. E. V. 1991. New developments in nutrition for growth enhancement. Pig Vet. J. N0. 27: 75-91. 
